\title{
Calculation of soil temperature at the intersection of the heating line of the underground gasket and gas pipeline taking into account real operating conditions
}

\author{
Guzel Akhmerova ${ }^{1 *}{ }^{[0000-0003-4030-8264]}$, Ayrat Sibgatov $^{1}$, Roman Badrutdinov ${ }^{1}$, Elza \\ Khaziakhmetova $^{2}$, and Rashid Maksudov ${ }^{3}$ \\ ${ }^{1}$ Kazan State University of Architecture and Engineering,420043, Zelenaya st., 1, Kazan, Russia \\ ${ }^{2}$ Kazan State Power Engineering University, 420066, Krasnoselskaya st., Kazan, Russia \\ ${ }^{3}$ Kazan National Research Technological University, 420015, Karl Marks st., Kazan, Russia
}

\begin{abstract}
Distances from the insulation shell of pipelines duringchannelless laying to utility networks are recommended by regulatory documents, but in real conditions it is not always possible to comply with these parameters. Calculations have been made to verify that the gas pipeline can be laid next to the supply pipeline of the heating network in the problematic section of the installation where these restrictions are not met. The soil temperature on the wall of the gas pipeline case is determined to exclude the heating condition of polyethylene pipes above $40{ }^{\circ} \mathrm{C}$ for the entire period of operation. Soil temperatures at the intersection of the heating line and the gas pipeline were determined taking into account the real operating conditions of the district heating networks, the peculiarities of regulating the coolant parameters of the Russian heat systems and the state of thermal insulation.
\end{abstract} Keywords: district heating networks, soil temperature, heat waste.

\section{Introduction}

According to SP 42-103-2003 «Design and construction of polyethylene gas pipelines and renovation of underground gas pipelines» at the intersection or parallel laying of the polyethylene gas pipeline with the heat path of the underground gasket, the distance between them is specified by calculation based on the conditions for excluding the possibility of heating polyethylene pipes above $40{ }^{\circ} \mathrm{C}$ for the entire period of operation.

Pipes in polyurethane foam insulation are a monolithic structure that includes: a steel pipe, a thermal insulation layer made of polyurethane and a protective shell. The thermal conductivity of polyurethane foams has been studied by experts for more than 20 years [1], and for the first time pipes in polyurethane insulation foams appeared in the late 1960s. The assessment of the technical state of pipes after natural or artificial aging (accelerated aging was carried out by applying three different elevated temperatures) is considered in the study

\footnotetext{
* Corresponding author: akhmerovaag@mail.ru
} 
[2]. The dependence of specific heat loss of the main pipes pre-insulated with polyurethane foam on coolant temperature in the range of $70-150^{\circ} \mathrm{C}$ is given in the work [3].

Most works on insulation of pipelines consider the tasks of reduction of heat losses during transportation [4-7], the effect of insulation thickness on cost parameters and corresponding savings in the heat supply system $[5,8]$, reduction of air pollution and real savingsof carbon emissions [9-10], impact on the environment of flue gases, the impact on the environment from the use of district heat supply systems [11] and district heating systems [12-16]. Studies [17-19] show the possibility of using pipelines made of polymer materials with high-efficiency thermal insulation in district heat supply systems. Thermal insulation materials as a tool for energy saving are considered in the work [20].

Russian district heating systems have their own features related to regulation, coolant parameters and a large percentage of wear and tear. When determining soil temperature and heat loss, it is important to take into account the real operating conditions of pipelines, since regulatory and design data are not always reliable [6].

Studies [21-22] numerically simulate the temperature field of the soil and calculate the temperature field of the soil around the underground pipeline during oil transportation, analyze the safety limits required for the temperature of the external surface of insulation of pipelines with the flow of superheated steam. The authors [23] consider the boundaries of the potential thermal impact zone provided that there are external ignition sources in case of possible emergency depressurization of the gas pipeline.

Since the issue of determining the soil temperature for underground pipelines was not considered in detail by the researchers, there is no detailed analysis of determining the soil temperature at the point of intersection of communications. Thus, this study is aimed at solving the problem of assessing the soil temperature at the intersection of the heating line of an underground gasket and a low-pressure gas pipeline, taking into account the real operating conditions of the heat supply system, the state of thermal insulation and soil humidification.

\section{Materials and methods}

It is necessary to prove the possibility of laying a gas pipeline at a distance of $0.4 \mathrm{~m}$ horizontally from the axis of the supply pipeline of the heat network of the underground channelless gasket in Kazan, on G. Barudi Street. The gas pipeline is located at a depth of $2.6 \mathrm{~m}$ from the ground surface, the depth of the heat pipeline is $H=1.6 \mathrm{~m}$. Standards allow for the smallest vertical clear distance of $0.2 \mathrm{~m}$ from the insulation casing of pipelines in a channelless laying to the gas pipeline.This condition is fully fulfilled with a large margin. The distance between the axes of the pipes of the heat network horizontally $K_{1,2}=0.5$ $m$.Design parameters of the coolant are $130 / 70{ }^{\circ} \mathrm{C}$. The average annual soil temperature at the depth of laying is $t_{o}=6.3{ }^{\circ} \mathrm{C}$, the soil characteristic is clay and loam, with a density of $\rho_{d r y}=1600 \mathrm{~kg} / \mathrm{m}^{3}$, the thermal conductivity of dry soil is $\lambda_{d r y}=0.33 \mathrm{~W} /\left(\mathrm{m} \cdot{ }^{\circ} \mathrm{C}\right)$. Heat pipelines operate under flooding conditions, which significantly affects the heat loss of underground heating lines. Soil humidity is not constant during the year. In this regard, it is of interest to evaluate he influence of volumetric soil humidity on heat flows, to determine the value of linear heat $\operatorname{losses} q, \mathrm{~W} / \mathrm{m}$, and soil temperature at the intersection of heat pipelines with a low-pressure gas pipeline. The heating line is a double-pipe gasket made of steel pipes with diameter of $D y=125 \mathrm{~mm}$ in polyurethane insulation foam, $\delta_{i s}=46 \mathrm{~mm}, \lambda_{i s}=0.033 \mathrm{~W} /\left(\mathrm{m} \cdot{ }^{\circ} \mathrm{C}\right)$. 


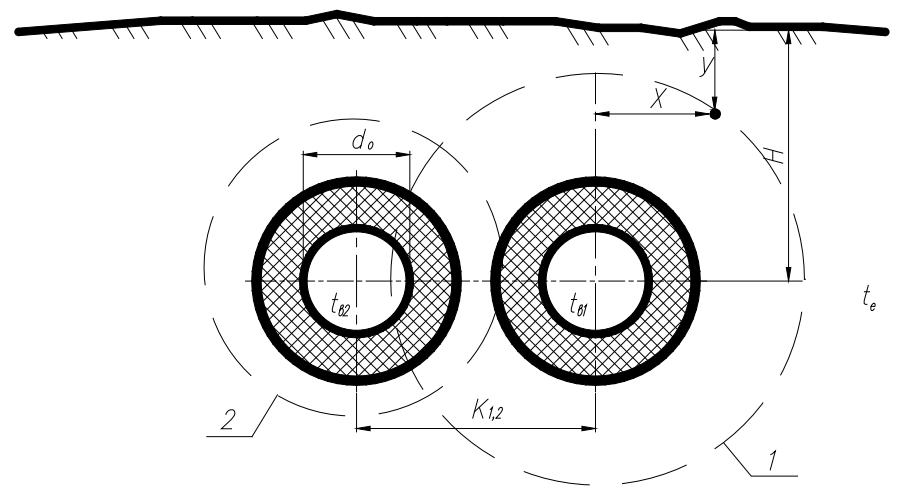

Fig. 1. Diagram of a double-pipe channelless gasket: 1- approximate temperature field formed in the soil around the supply pipeline of the heat network; 2 - same around return pipeline.

Temperature at any point of soil around double-pipeheat pipe of channelless gasket is determined by formula:

$$
t=t_{e}+\frac{q_{1}}{2 \pi \lambda_{s}} \ln \sqrt{\frac{x^{2}+(y+\dot{I})^{2}}{x^{2}+(y-\dot{I})^{2}}}+\frac{q_{2}}{2 \pi \lambda_{s}} \ln \sqrt{\frac{\left(x-\hat{E}_{l, 2}\right)^{2}+(y+\dot{I})^{2}}{\left(x-\hat{E}_{l, 2}\right)^{2}+(y-\dot{I})^{2}}}
$$

where $t_{e}$ - temperature of soil, or outdoor air, ${ }^{\circ} \mathrm{C}$,(see fig. 1 ); $q_{1}$ and $q_{2}-$ specific heat losses from supply and return pipelines in soil, $W / m ; \lambda_{s}-$ soil thermal conductivity coefficient, $\mathrm{W} /\left(\mathrm{m} \cdot{ }^{\circ} \mathrm{C}\right) ; x$ and $y$-the distance of the considered point from the axis of the supply pipeline of the heat network and from the soil surface; $H$ - the depth of laying of an axis of the pipeline, $m ; K_{1,2}$ - the distance between the axes of the heat pipes, $m$, (see fig. 1).

With a double-pipe channelless gasket, as a result of heat losses around pipelines, temperature fields are formed in the soil, which contribute to reducing the heat loss of each pipe separately. Reducing heat loss will be the greater, the higher the soil temperature around the adjacent pipeline.

Heat losses of double-pipeheat networks during channelless laying, $\mathrm{W} / \mathrm{m}$ :

$$
\begin{aligned}
& q_{1}^{L}=\frac{\left(t_{\hat{a} 1}-t_{e}\right)\left(R_{i s 2}^{L}+R_{s}\right)-\left(t_{\hat{a} 2}-t_{e}\right) \cdot R_{i}}{\left(R_{i s l}^{L}+R_{s}\right)\left(R_{i s 2}^{L}+R_{s}\right)-R_{i}^{2}} K \\
& q_{2}^{L}=\frac{\left(t_{\hat{a} 2}-t_{e}\right)\left(R_{i s 1}^{L}+R_{s}\right)-\left(t_{\hat{a} 1}-t_{e}\right) \cdot R_{i}}{\left(R_{i s 2}^{L}+R_{s}\right)\left(R_{i s l}^{L}+R_{s}\right)-R_{i}^{2}} K
\end{aligned}
$$

where $t_{61}, t_{62}$ - coolant temperature in supply and return pipelines of heat network, ${ }^{\circ} \mathrm{C} ; t_{e}-$ temperature of the external environment, ${ }^{\circ} \mathrm{C} ; R_{i s 1}^{L}, R_{i s 2}^{L}-$ thermal resistance of supply and return pipelines insulation, $m \cdot{ }^{\circ} \mathrm{C} / W ; R_{s}$ - thermal resistance of the soil during channelless laying, $m \cdot{ }^{\circ} \mathrm{C} / W ; R_{i}$ - thermal resistance caused by thermal interaction of two pipes, $m \cdot{ }^{\circ} \mathrm{C} / W ; \mathrm{K}$-coefficient of additional losses.

Thermal resistanceinsulation of supply and return pipelines:

$$
\begin{gathered}
R_{i s 1}^{L}=\frac{1}{2 \cdot \pi \cdot \lambda_{i s}} \cdot \ln \frac{d_{o 1}+2 \delta_{i s 1}}{d_{o 1}}, \\
R_{i s 2}^{L}=\frac{1}{2 \cdot \pi \cdot \lambda_{i s}} \cdot \ln \frac{d_{o 2}+2 \delta_{i s 2}}{d_{o 2}},
\end{gathered}
$$

where $d_{o}$ - outer diameter of pipes, $m$ (as shown in Fig. 1). 
The thermal resistance of the soil during channelless laying, $m \cdot{ }^{\circ} \mathrm{C} / \mathrm{W}$, is determined by the Forgheimer formula:

$$
\begin{gathered}
R_{s}=\frac{1}{2 \cdot \pi \cdot \lambda_{s}} \cdot \ln \frac{4 H}{d} \\
R_{s}=\frac{1}{2 \pi \lambda_{s}} \ln \left[\frac{2 H}{d}+\sqrt{\left(\frac{2 H}{d}\right)^{2}-1}\right]
\end{gathered}
$$

Where $\lambda_{s}$ - soil thermal conductivity coefficient, $W /\left(m \cdot{ }^{\circ} \mathrm{C}\right) ; \mathrm{H}$ - depth of laying of an axis of the pipeline, $m ; d$ - outer diameter of pipes taking into account thermal insulation thickness, $m$.

Thermal resistance caused by thermal interaction of two pipes:

$$
R_{i}=\frac{\ln \sqrt{1+\left(\frac{2 H}{K_{l, 2}}\right)^{2}}}{2 \pi \cdot \lambda_{s}},
$$

where $K_{l, 2}-$ distance between pipe axes horizontally, $m$.

\section{Results and discussion}

According to SP 42-103-2003 «Design and construction of polyethylene gas pipelines and renovation of underground gas pipelines» at the intersection or parallel laying of a polyethylene gas pipeline with a channelless heat distribution, the distance between them is specified by calculation based on the conditions for excluding the possibility of heating polyethylene pipes above $40{ }^{\circ} \mathrm{C}$ for the entire period of operation.

In Kazan, combined sources of thermal and electric energy provide most of the heat load of the city. The calculated parameters of the temperature schedule are $130 / 65^{\circ} \mathrm{C}$, with optimization on $115 / 65{ }^{\circ} \mathrm{C}$ (supply / return) as shown infig. 2. The average monthly coolant temperatures in January is $92.1 / 54.9{ }^{\circ} \mathrm{C}$ - according to temperature schedule $t_{e}=-11.6{ }^{\circ} \mathrm{C}$.

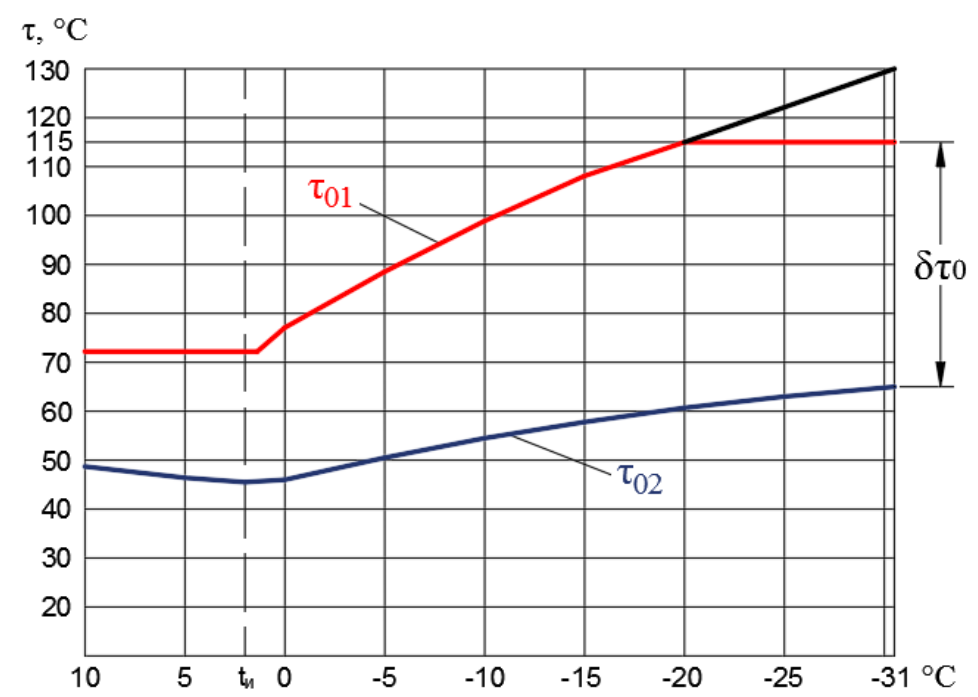

Fig. 2. Water temperature chart in supply and return lines of the heat network with qualitative regulation of heating load. 
Calculations were made for various modes of operation of thermal conductors with simultaneous moistening of the soil from 0 to $48 \%$ (insulation is not moistened). The thermal conductivity of the soil is also not a constant value, it depends on humidity. The thermal conductivity of the soil increases dramatically as humidity increases, since the thermal conductivity of the air displaced by the water from the soil pores is approximately 25 times less than the thermal conductivity of the water. Influence of soil thermal conductivity coefficient on heat losses from pre-insulated pipes during operation is considered in the study [24].

Dependence of the coefficient of thermal conductivity of wet soils on mass humidity:

$\mathrm{W}_{s}=0 \%, \lambda_{s}=0.33 \mathrm{~W} /\left(\mathrm{m}^{\circ}{ }^{\circ} \mathrm{C}\right)-$ absolutely dry soil; $\mathrm{W}_{s}=16 \%, \lambda_{s}=0.96 \mathrm{~W} /\left(\mathrm{m}^{\circ}{ }^{\circ} \mathrm{C}\right)-$ wet soil (natural humidity); $\mathrm{W}_{s}=32 \%, \lambda_{s}=1.33 \mathrm{~W} /\left(\mathrm{m} \cdot{ }^{\circ} \mathrm{C}\right)-$ wet soil; $\mathrm{W}_{s}=48 \%, \lambda_{s}=1.63$ $\mathrm{W} /\left(\mathrm{m} \cdot{ }^{\circ} \mathrm{C}\right)$ - water-saturated soil.

Calculations were carried out during the design operation mode of the pipelines and in the absence of insulation on both pipelines, for the following conditions:

- average annual coolant parameters are $65 / 50{ }^{\circ} \mathrm{C}$ and average annual soil temperature is $t_{e}=6.3^{\circ} \mathrm{C}$;

- calculated parameters of the coolantare $130 / 70{ }^{\circ} \mathrm{C}$, and soil temperature in January is ${ }^{\circ} \mathrm{C} t_{e}=3.1$, at a depth of laying of a heating conduit is $\mathrm{H}=1.6 \mathrm{~m} \mathrm{[25]}$;

- average monthly coolant temperatures in January is $94 / 55^{\circ} \mathrm{C}$ and soil temperature for January is $t_{e}=3.1^{\circ} \mathrm{C}$;

- calculated parameters of the coolantare $115 / 60{ }^{\circ} \mathrm{C}$, and soil temperature in January is $t_{e}=3.1^{\circ} \mathrm{C}$, at a depth of laying of a heating conduit is $\mathrm{H}=1.6 \mathrm{~m}$ [25].

The results of the calculations are summarized in tables 1-4.Using the calculation procedure of SP 61.13330.2012 «Designing of thermal insulation of equipment and pipelines,» it is not possible to take into account the partial destruction of polyurethane foam insulation, therefore, calculations are carried out for the most unfavorable conditions in the absence of insulation on both pipelines. No humidification of polyurethane foam insulation is provided - humidification coefficient $\mathrm{K}=1.0$ is used in the calculation for lowmoisture, wet and water-saturated soil, since the modern waterproofing coating of preinsulated pipes eliminates the possibility of humidification of insulation during operation. In the previous version of building codes for polyurethane foam insulation, this coefficient changed in the range $1.0 \div 1.1$.

Table 1. Soil temperature at the point of intersection of double-pipeheat networks with low-pressure gas pipeline. Average annual coolant parameters are $65 / 50{ }^{\circ} \mathrm{C}$, average annual soil temperature iste $=6.3{ }^{\circ} \mathrm{C}$.

\begin{tabular}{|c|c|c|c|c|}
\hline $\begin{array}{c}\text { Soil } \\
\text { moisture, } \\
\% \text { (clays } \\
\text { and } \\
\text { loams) }\end{array}$ & \multicolumn{2}{|c|}{ Calculation mode of the pipelines } & \multicolumn{2}{|c|}{ If there is no insulation on both pipelines } \\
\cline { 2 - 5 } & Heat loss, W/m & $\begin{array}{c}\text { Soil temperature } \\
\text { on the wall of the } \\
\text { gas pipeline case }\end{array}$ & Heat loss, W/m & $\begin{array}{c}\text { Soil temperature } \\
\text { on the wall of the } \\
\text { gas pipeline case }\end{array}$ \\
\hline 0 & $\begin{array}{l}q_{1}^{L}=27.45 \\
q_{2}^{L}=16.92\end{array}$ & 23.23 & $\begin{array}{l}q_{1}^{L}=28.76 \\
q_{2}^{L}=17.48\end{array}$ & 23.95 \\
\hline 16 & $q_{1}^{L}=32.57$ & 19.98 & $\begin{array}{l}q_{1}^{L}=43.14 \\
q_{2}^{L}=26.22\end{array}$ & 23.95 \\
\hline 32 & $q_{2}^{L}=21.17$ & 14.98 & $\begin{array}{l}q_{1}^{L}=86.28 \\
q_{2}^{L}=52.44\end{array}$ & 23.95 \\
\hline 38 & $q_{1}^{L}=40.28$ & 14.92 & $\begin{array}{l}q_{1}^{L}=92.23 \\
q_{2}^{L}=56.06\end{array}$ & 23.95 \\
\hline
\end{tabular}


Table 2. Soil temperature at the point of intersection of double-pipeheat networks with low-pressure gas pipeline. Design parameters of coolant are $130 / 70{ }^{\circ} \mathrm{C}$, soil temperature for January is $t_{e}=3.1^{\circ} \mathrm{C}$

\begin{tabular}{|c|c|c|c|c|}
\hline \multirow{2}{*}{$\begin{array}{c}\text { Soil } \\
\text { moisture, \% } \\
\text { (clays and } \\
\text { loams) } \\
\end{array}$} & \multicolumn{2}{|c|}{ Calculation mode of the pipelines } & \multicolumn{2}{|c|}{ If there is no insulationon both pipelines } \\
\hline & Heat loss, W/m & $\begin{array}{c}\text { Soil temperature on } \\
\text { the wall of the gas } \\
\text { pipeline case }\end{array}$ & Heat loss, W/m & $\begin{array}{c}\text { Soil temperature on } \\
\text { the wall of the gas } \\
\text { pipeline case }\end{array}$ \\
\hline 0 & $\begin{array}{l}q_{1}^{L}=63.06 \\
q_{2}^{L}=20.91\end{array}$ & 34.95 & $\begin{array}{l}q_{1}^{L}=66.31 \\
q_{2}^{L}=21.20\end{array}$ & 36.28 \\
\hline 16 & $\begin{array}{l}q_{1}^{L}=73.66 \\
q_{2}^{L}=28.06\end{array}$ & 28.85 & $\begin{array}{l}q_{1}^{L}=99.47 \\
q_{2}^{L}=31.80\end{array}$ & 36.28 \\
\hline 32 & $\begin{array}{l}q_{1}^{L}=89.32 \\
q_{2}^{L}=39.65\end{array}$ & 19.45 & $\begin{array}{c}q_{1}^{L}=198.93 \\
q_{2}^{L}=63.60\end{array}$ & 36.28 \\
\hline 38 & $\begin{array}{l}q_{1}^{L}=90.60 \\
q_{2}^{L}=40.64\end{array}$ & 18.67 & $\begin{array}{c}q_{1}^{L}=212.65 \\
q_{2}^{L}=67.99\end{array}$ & 36.28 \\
\hline
\end{tabular}

Table 3. Soil temperature at the point of intersection of double-pipe heat networks with low-pressure gas pipeline. Average monthly coolant temperatures in Januaryis $92.1 / 54.9^{\circ} \mathrm{C}$, soil temperature is $t_{e}=3.1^{\circ} \mathrm{C}$.

\begin{tabular}{|c|c|c|c|c|}
\hline \multirow{2}{*}{$\begin{array}{l}\text { Soil } \\
\text { moisture, \% } \\
\text { (clays and } \\
\text { loams) }\end{array}$} & \multicolumn{2}{|c|}{ Calculation mode of the pipelines } & \multicolumn{2}{|c|}{ If there is no insulationon both pipelines } \\
\hline & Heat loss, W/m & $\begin{array}{c}\text { Soil temperature on } \\
\text { the wall of the gas } \\
\text { pipeline case }\end{array}$ & Heat loss, W/m & $\begin{array}{c}\text { Soil temperature on } \\
\text { the wall of the gas } \\
\text { pipeline case }\end{array}$ \\
\hline 0 & $\begin{array}{l}q_{1}^{L}=43.57 \\
q_{2}^{L}=17.44\end{array}$ & 26.28 & $\begin{array}{l}q_{1}^{L}=45.77 \\
q_{2}^{L}=17.81\end{array}$ & 27.25 \\
\hline 16 & $\begin{array}{l}q_{1}^{L}=51.09 \\
q_{2}^{L}=22.81\end{array}$ & 21.84 & $\begin{array}{l}q_{1}^{L}=68.66 \\
q_{2}^{L}=26.71\end{array}$ & 27.25 \\
\hline 32 & $\begin{array}{l}q_{1}^{L}=62.25 \\
q_{2}^{L}=31.45\end{array}$ & 14.99 & $\begin{array}{c}q_{1}^{L}=137.32 \\
q_{2}^{L}=53.42\end{array}$ & 27.25 \\
\hline 38 & $\begin{array}{l}q_{1}^{L}=63.16 \\
q_{2}^{L}=32.19\end{array}$ & 14.25 & $\begin{array}{c}q_{1}^{L}=146.79 \\
q_{2}^{L}=57.10\end{array}$ & 27.25 \\
\hline
\end{tabular}

Table 4.Soil temperature at the point of intersection of double-pipe heat networks with low-pressure gas pipeline. Design parameters of coolant are $115 / 60{ }^{\circ} \mathrm{C}$, soil temperature is $t_{e}=3.1^{\circ} \mathrm{C}$.

\begin{tabular}{|c|c|c|c|c|}
\hline \multirow{2}{*}{$\begin{array}{c}\text { Soil } \\
\text { moisture, \% } \\
\text { (clays and } \\
\text { loams) }\end{array}$} & \multicolumn{2}{|c|}{ Calculation mode of the pipelines } & \multicolumn{2}{|c|}{ If there is no insulation on both pipelines } \\
\cline { 2 - 5 } & Heat loss, W/m & $\begin{array}{c}\text { Soil temperature on } \\
\text { the wall of the gas } \\
\text { pipeline case }\end{array}$ & Heat loss, W/m & $\begin{array}{c}\text { Soiltemperature on } \\
\text { the wall of the gas } \\
\text { pipeline case }\end{array}$ \\
\hline 0 & $q_{1}^{L}=55.89$ & 30.83 & $\begin{array}{c}q_{1}^{L}=58.79 \\
q_{2}^{L}=17.44\end{array}$ & 31.98 \\
\hline$q_{2}^{L}=17.25$ & 25.52 & $\begin{array}{c}q_{1}^{L}=88.18 \\
q_{2}^{L}=26.15\end{array}$ & 31.98 \\
\hline \multirow{2}{*}{16} & $q_{1}^{L}=65.20$ & 17.34 & $\begin{array}{c}q_{1}^{L}=176.36 \\
q_{2}^{L}=52.31\end{array}$ & 31.98 \\
\hline 32 & $q_{2}^{L}=23.39$ & 16.65 & $\begin{array}{c}q_{1}^{L}=188.52 \\
q_{2}^{L}=55.91\end{array}$ & 31.98 \\
\hline \multirow{2}{*}{38} & $q_{1}^{L}=78.94$ & & & \\
\hline
\end{tabular}


Table 1-4 shows that the minimum heat loss is typical for dry soil and they increase many times depending on soil humidification. Soil temperature on the wall of the gas pipeline case for the design mode of operation of pipelines in this case is the maximum, but does not exceed the allowable $40{ }^{\circ} \mathrm{C}$.

In case of complete absence of insulation on the pipeline, the maximum temperature on the wall of the gas pipeline case is $36.28{ }^{\circ} \mathrm{C}$ in January, with calculated coolant parameters of $130 / 70{ }^{\circ} \mathrm{C}$ and soil temperature $t_{e}=3.1^{\circ} \mathrm{C}$ at the depth of the heat pipeline $H=1.6 \mathrm{~m}$.

\section{Conclusions}

Based on the studies performed, a solution was obtained to the current scientific and practical task of assessing the soil temperature at the intersection of the heating line of the underground gasket and the low-pressure gas pipeline, taking into account real operating conditions.

The received results show that use of a polyethylene case of PE100 GAZ of SDR11$225 \times 20.5$ is admissible since temperature on a case will not exceed $40{ }^{\circ} \mathrm{C}$ at calculated parameters of the coolant of $130 / 70^{\circ} \mathrm{C}$ even with total destruction of thermal isolation.

\section{References}

1. J. W. Wu, W. F. Sung, H. Sen Chu, in Int. J. Heat Mass Transf., 42(12), 2211-2217 (1999)

2. N. Yarahmadi, J. H. Sällström, in 14th Int. Symp. Dist. Heat. Cool. (2014)

3. G. N. Baidyusenov, S. K. Abildinova, A. A. Elemanova, R. A. Sadykov, Izvestija KGASU, 1(51), 109-117 (2020).

4. R. Zwierzchowski, O. Niemyjski, in IOP Conf. Ser. Mater. Sci. Eng. (2019) DOI: 10.1088/1757-899X/471/4/042019

5. R. Lund, S. Mohammadi, in Appl. Therm. Eng. (2016) DOI: 10.1016/j.applthermaleng.2015.12.015

6. G. M. Akhmerova, A.R. Zalyalova, R.M. Mukhametshina, IOP Conf. Ser.: Mater. Sci. Eng., 890, 012153 (2020) DOI: 10.1088/1757-899X/890/1/012153

7. G. M. Akhmerova, A. V. Fedorov, Izvestija KGASU, 2(36), 117-122 (2016)

8. A. Daşdemir, T. Ural, M. Ertürk, A. Keçebaş, Appl. Therm. Eng. (2017) DOI: 10.1016/j.applthermaleng.2017.04.001

9. M. A. Sayegh, J. Danielewicz, T. Nannou, M. Miniewicz, P. Jadwiszczak, K. Piekarska, H. Jouhara, Renew. Sustain. Energy Rev. (2017) DOI: 10.1016/j.rser.2016.02.023

10. Y. Başoğul, C. Demircan, A. Keçebaş, Appl. Therm. Eng. (2016) DOI: 10.1016/j.applthermaleng.2016.03.010

11. Y. Volodin, O. Marfina, M. Tsvetkovich, IOP Conf. Ser.: Mater. Sci. Eng., 890, 012160 (2020) DOI:10.1088/1757-899X/890/1/012160

12. H. Wang, H. Meng, T. Zhu, Energy Convers. Manag., 157, 71-85 (2018) DOI: 10.1016/j.enconman.2017.11.062

13. J. Danielewicz, B. Śniechowska, M. A. Sayegh, N. Fidorów, H. Jouhara, Energy, 108, 172-184 (2016) DOI: 10.1016/j.energy.2015.07.012

14. R. Ovando-Castelar, J. I. Martínez-Estrella, A. García-Gutierrez, I. Canchola-Félix, P. Jacobo-Galván, C. Miranda-Herrera, O. Mora-Perez, World Geotherm. Congr. (2015)

15. S. Werner, Energy (2017) DOI: 10.1016/j.energy.2017.04.045

16. H. Lund, P. A. Østergaard, M. Chang, S. Werner, S. Svendsen, P. Sorknæs, J. E. Thorsen, F. Hvelplund, B. O. G. Mortensen, B. V. Mathiesen, C. Bojesen, N. Duic, X. Zhang, B. Möller, Energy (2018) DOI: 10.1016/j.energy.2018.08.206 
17. I. Baldvinsson, T. Nakata, Energy, 95, 155-174 (2016) DOI: 10.1016/j.energy.2015.11.057

18. Y. Başoĝul, A. Keçebaş, Energy (2011) DOI: 10.1016/j.energy.2011.07.049

19. I. N. Solomin, A. Z. Daminov, R. A. Sadykov, Izvestija KGASU, 2(44), 184-192 (2018)

20. G. Deshmukh, P. Birwal, R. Datir, S. Patel, J. Food Process. Tchnol., (2017) DOI: $10.4172 / 2157-7110.1000670$

21. Gu Fu Xin, Ma Gui Yang, Sun Nan, Li Xiaoling, A numerical calculation on soil moisture, heat couple temperature field around pipelines in the process of alternate transportation of cool-hot crude oil (2009) DOI:10.1061/41073(361)38

22. G. M. Zaki, A. M. Al-Turki, Heat Transf. Eng., (2000) DOI: $10.1080 / 01457630050144514$

23.E. Varsegova, E. Dresvyannikova, L. Osipova, R. Sadykov International Scientific Conf. on Energy, Environmental and Construction Engineering (2019) DOI https://doi.org/10.1051/e3sconf/201914006007

24. M. Perpar, Z. Rek, S. Bajric, I. Zun, Energy (2012) DOI: 10.1016/j.energy.2012.06.037

25. All about oil and gas, URL: neftyaga.ru/v-pomosch-rabotniku-gazovoypromishlennosti/temperatura-grunta-v-s-na-razlichnich-glubinach-v-nekotorichpunktach-sssr, (last accessed 23.03.2021) 